\title{
Pott's Puffy Tumor: A New Complication of HIV
}

Saif Ibrahim, Farah AI-Saffar, Robert W Regenhardt and Nilmarie Guzmán*

Shands Jacksonville Medical Center, USA

*Corresponding author: Dr. Nilmarie Guzman, Shands Jacksonville Medical Center, 655 W 8th St, Jacksonville, FL 32209, USA, Tel: +1 904-383-1006; E-mail: nilmarie.guzman@jax.ufl.edu

Received date: Mar 26, 2014; Accepted date: Apr 21, 2014; Published date: Apr 28, 2014

Copyright: (c 2014 Ibrahim, et al. This is an open-access article distributed under the terms of the Creative Commons Attribution License, which permits unrestricted use, distribution, and reproduction in any medium, provided the original author and source are credited.

\begin{abstract}
Background: First described in 1760, Pott's Puffy Tumor (PPT) is frontal bone osteomyelitis and sub-periosteal abscess complicated by frontal sinusitis. Currently, it's a very rare complication due to the advent of Antibiotics and even more rare in adults than adolescents as developmental differences in cranial anatomy have been presumed to be the reason why more cases are seen in the younger age group. Only 32 adult cases are reported since 1990 to date. Most common organisms being streptococci, staphylococci, and anaerobes.

The Case: 51 year old African American male patient presented with worsening frontal headache and a painful swelling on the forehead along with diplopia. Past history is positive for HIV, diagnosed 7 years earlier, not on antiretroviral therapy, in addition to surgery for head trauma 13 years prior. With appropriate medical and surgical management, the patient had significant improvement on examination and his diplopia resolved. Cultures from drainage grew Propioni bacterium sp.

Discussion: We present a unique case of PPT on a patient with a history of head trauma and HIV, both acting as predisposing factors for his delayed presentation. This link may suggest a possible epidemiological transition in the trends of comorbidities predisposing to PPT since HIV prevalence has been in the rise. It is also a case with the longest documented latency period between head trauma and PPT presentation date. This, combined with unusual anaerobic bacterial isolates, make this new case report a pioneer in pointing out PPT's association with novel risk factors.
\end{abstract}

\section{Background}

The first description of Pott's puffy tumor (PPT) was in 1760 by Sir Percival Pott. He observed a local sub-periosteal abscess secondary to traumatic frontal bone infection. In 1775, he reported another case that resulted after frontal sinusitis. PPT almost always occurs as a result of infection drainage through venous sinuses to the frontal sinus or through direct extension through the bone itself. The end result is frontal bone osteomyelitis and the formation of sub-periosteal abscesses. Since the advent of antibiotics, this disorder has become exceedingly rare and there is little literature about its prevalence [1]. PPT shows a predilection for males [2,3]. It is also observed much more commonly in adolescents [4]. To our knowledge, only 32 prior cases of adult PPT have been reported [5]. Perhaps two of the most severe complications are subdural empyema and brain abscess. These are noted to occur in 60-80 percent of all presenting cases of PPT, though less likely in adult patients $[3,6]$.

The most common presenting symptoms include frontal headache, fever, purulent rhinorrhea, and facial swelling $[7,8]$. It can present acutely, which is more common, or as a chronic condition with recurring exacerbations [9]. The infectious etiology varies from case to case, but the most common organisms are streptococci, staphylococci, and anaerobes [3,9]. Examination of the published cases shows that most patients required surgical drainage in addition to antibiotic therapy [5].

\section{Case Report}

A 51 year old African American male patient presented with worsening frontal headache and a painful swelling on the forehead along with diplopia. Past history is positive for HIV infection, diagnosed 7 years earlier for which the patient was not taking antiretroviral therapy in addition to surgery for head trauma 13 years prior. The pain was localized to the mid-forehead. It started as small swelling more than a year ago during which it had waxed and waned in size. During the last month that preceded presentation the swelling was increasing in size along with pain. Patient started to develop diplopia over the 2 weeks prior to admission. The patient denied fever, sinus pressure, rhinorrhea, or any other recent illness.

The patient had a history of previous frontal sinus fracture secondary to trauma, requiring craniotomy with open reduction and internal fixation via a coronal approach 13 years prior. He was also diagnosed with HIV seven years ago, with his last documented viral load being 50 ( 3 months prior to admission) and his last CD4 count being 507 (4 months prior to admission). He had been off his antiretroviral regimen because of adverse reactions for over 4 months. He also had a documented negative PPD (2 months prior). He was homeless, worked in a scrap yard with sheet metal, and had a 15 pack year smoking history.

On presentation, he was afebrile with normal vital signs. The physical examination revealed a $3 \mathrm{~cm}$ round mildly tender area of swelling along the forehead near the midline. There were no overlying skin changes suggestive of cellulitis or abscess (Figure 1). 
Citation: Ibrahim S. Al-Saffar F, Regenhardt RW, Guzmán N (2014) Pott's Puffy Tumor: A New Complication of HIV. JGPR 2: 154. doi:

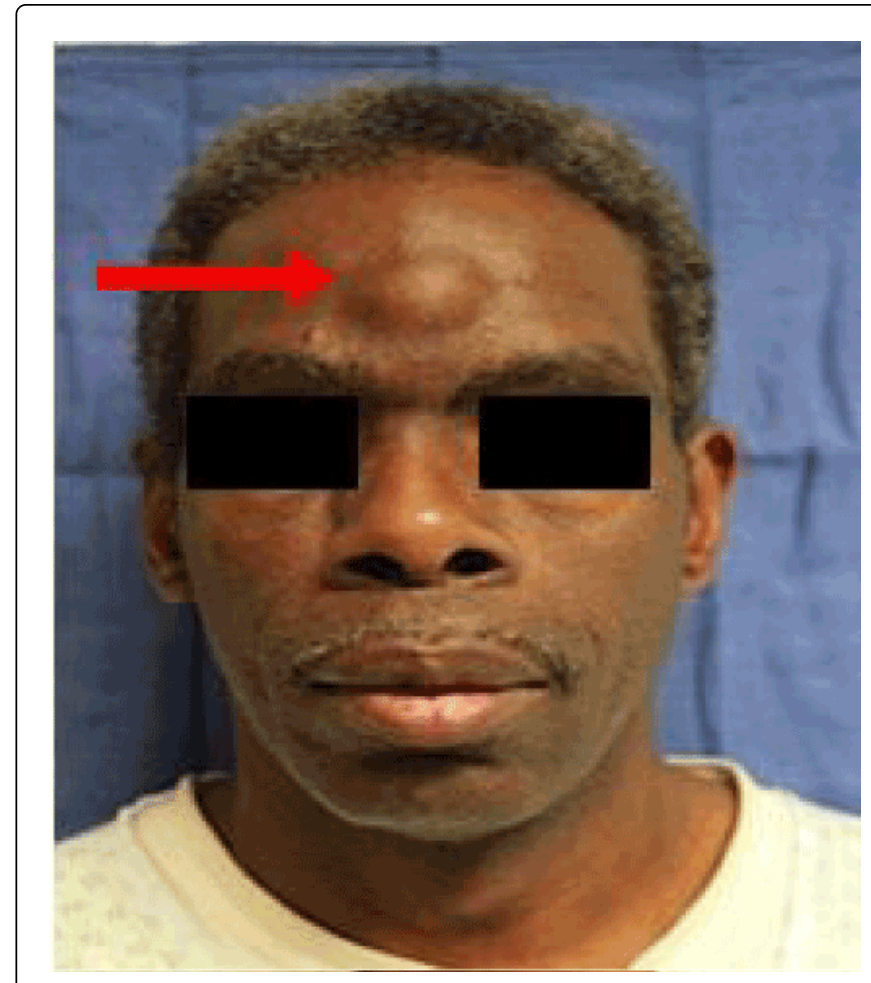

Figure 1: Picture of the patient on presentation.

He demonstrated disconjugate gaze upon extraocular movement, with his left eye restricted on lateral gaze. He had no other focal neurological deficits. The remainder of his head and neck examination was normal.

Laboratory workup revealed a CD4 count of 361 on admission. The patient also had lymphocytopenia ( 3.3 thousand $/ \mathrm{mm}^{3}$ ) with decreased neutrophil count (21), elevated \% monocytes (8), and elevated eosinophils (26). He also had an absolute neutropenia $\left(0.7\right.$ thou $\left./ \mathrm{mm}^{3}\right)$ and mild anemia (hemoglobin $12.6 \mathrm{~g} / \mathrm{dL}$, hematocrit $38.2 \%$ ). Basic metabolic panel was normal.

Radiologic workup included a sinus CT which revealed opacification of the frontal sinus, in addition to the ethmoid sinuses. There was also dehiscence of the frontal table bone with transcalvarial extension of soft tissue edema into the soft tissues of the overlying forehead (Figures 2 and 3). No intracranial or intracerebral extension was present.

The patient was started on empiric antibiotic coverage with significant improvement in the size of the swelling and total resolution of the diplopia after 24 hours of antibiotic coverage. The patient then underwent endoscopic sinus surgery to reestablish frontal sinus drainage. Intra-operative findings revealed adhesions of the frontal drainage pathway with trapped frontal sinus infected mucocele, which, upon opening, revealed frank mucopurulence. The culture results from this fluid revealed coagulase negative Staphylococcus and Propioni bacterium sp., both susceptible Topiperacillin-tazobactam. Acid fast and fungal cultures were negative. Having been timely diagnosed and appropriately treated, the patient showed great improvement, and was discharged on piperacillin-tazobactam for a total of 6 weeks of treatment. Follow up labs 10 days after discharge showed a CD4 count of 361 and viral load of 12,900 copies and a diagnosis of AIDS was documented at the time.

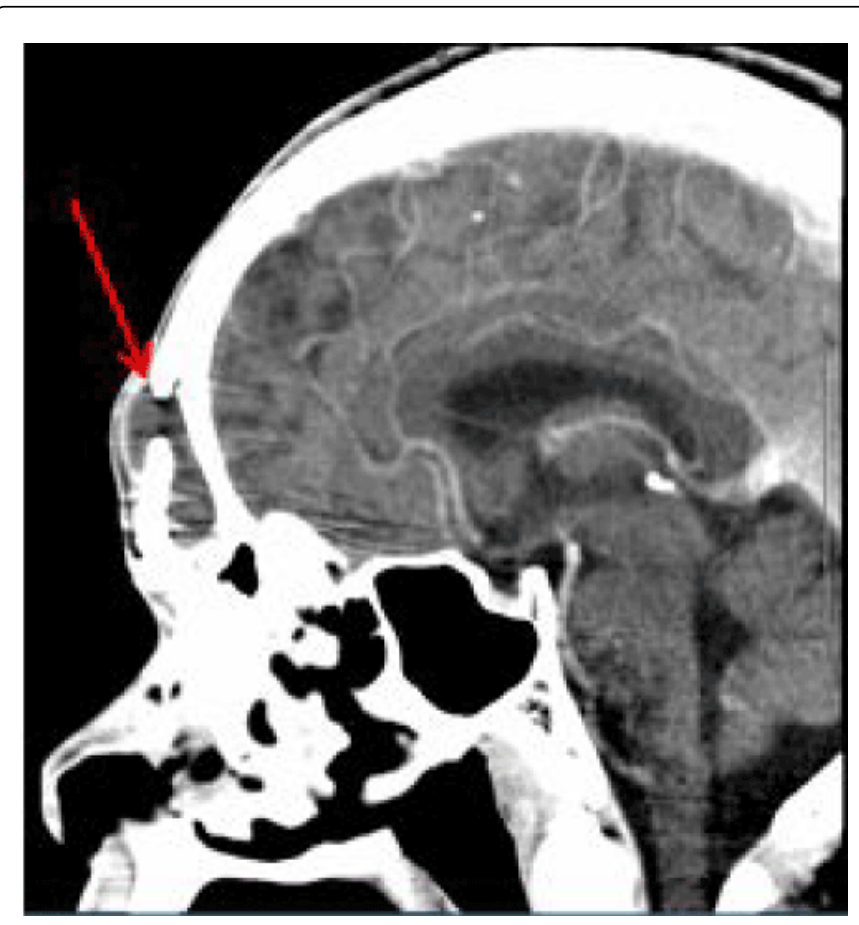

Figure 2: CT scan (sagital section) showing frontal sinus opacity along with dehiscence of the frontal table of the frontal bone.

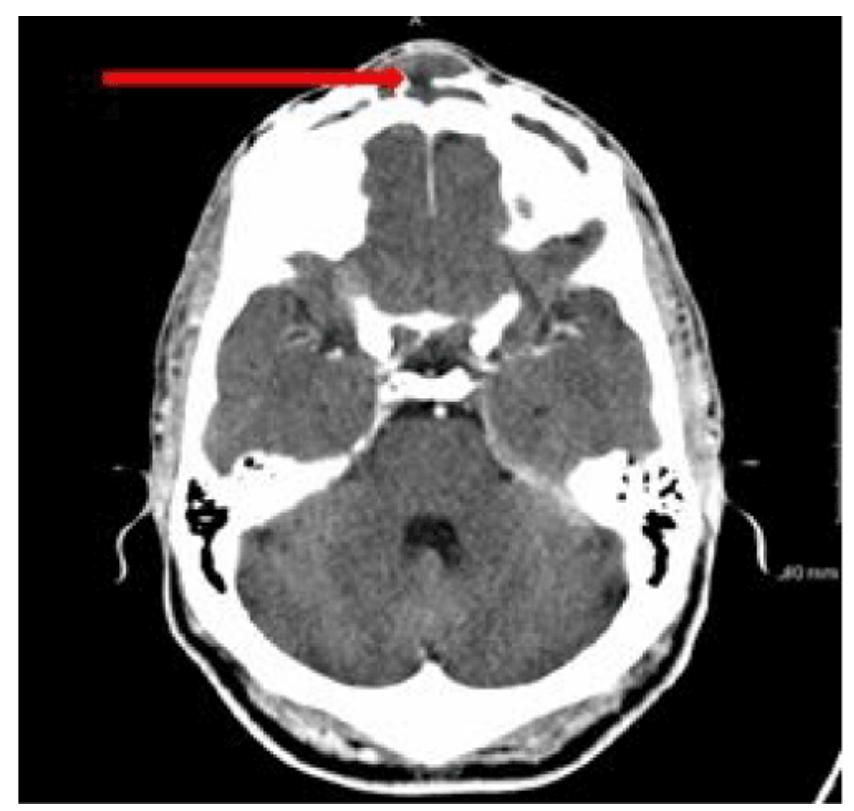

Figure 3: CT scan section showing the sub-periosteal abscess underlying the skin of the forehead. 


\section{Discussion}

Sir Percival Pott first described this condition in 1760. Interestingly, he believed it was caused by trauma to the frontal sinus bone. In 1775 he had a patient with the same presentation after frontal sinusitis and this led him to conclude that the etiology is more infectious rather than traumatic.

Our case presentation is unique because it encompasses both theories as inter-related causes for PPT. The head trauma 13 years prior to our patient presentation resulted in displaced fractures of the frontal table of the frontal sinus and the naso-orbital-ethmoid complex, both were surgically repaired. The resultant traumaticallyaltered cranial anatomy is one identified cause for PPT, but with a thirteen-year gap, making the case one with the longest trauma-PPT latency period reported to date [5]. Additionally, the frontal sinus drainage pathway became dysfunctional due to the aforementioned anatomic changes. We believe that this, together with impaired immunity secondary to HIV infection, predisposed the patient to frontal sinusitis as the bacterial isolates were consistent with those causing sinusitis and soft tissue infections in HIV patients [10-12]. To our knowledge, there are only two reported cases of PPT in HIV patients $[13,14]$.

PPT is rare in general, and being even rarer in adults. It is more common in children due to the fact that their skull and sinus anatomy facilitates the spread of infection [15]. The true causes and mechanism of developing PPT are still unclear. Fortunately, proper treatment with antibiotics/surgery is helpful in the majority of cases [5]. Left untreated, PPT may lead to complications that include -but are not limited to: meningitis, dural empyema, dural vein thrombosis, and brain abscess [3].

This is a case of a rare pathology (PPT); it also highlights a link not usually reported with HIV. This link may suggest a possible epidemiological transition in the trends of comorbidities predisposing to PPT since HIV prevalence continues to be on the rise, a concern shared by our colleagues in South Africa [16]. It is also a case with the longest documented latency period between head trauma and PPT presentation date. This, combined with the unusual bacterial isolates of Propioni bacterium sp., make this a distinct case pointing out PPT's association with novel risk factors.

\section{Conflict of Interest}

The author(s) declare(s) that there is no conflict of interests regarding the publication of this article.

\section{References}

1. Goldberg AN, Oroszlan G, Anderson TD (2001) Complications of frontal sinusitis and their management. Otolaryngol Clin North Am 34: 211-225.

2. Forgie SE, Marrie TJ (2008) Pott's puffy tumor. Am J Med 121: 1041-1042.

3. Ketenci I, Unlü Y, Tucer B, Vural A (2011) The Pott's puffy tumor: a dangerous sign for intracranial complications. Eur Arch Otorhinolaryngol 268: 1755-1763.

4. Karaman E, Hacizade Y, Isildak H, Kaytaz A (2008) Pott's puffy tumor. J CraniofacSurg 19: 1694-1697.

5. Akiyama K, Karaki M, Mori N (2012) Evaluation of adult Pott's puffy tumor: our five cases and 27 literature cases. Laryngoscope 122: 2382-2388.

6. Ibarra S, Aguirrebengoa K, Pomposo I, Bereciartúa E, Montejo M, et al. (1999) [Osteomyelitis of the frontal bone (Pott's puffy tumor). A report of 5 patients]. EnfermInfeccMicrobiolClin 17: 489-492.

7. Bannon PD, McCormack RF (2011) Pott's puffy tumor and epidural abscess arising from pansinusitis. J Emerg Med 41: 616-622.

8. Collet S, Grulois V, Eloy P, Rombaux P, Bertrand B (2009) A Pott's puffy tumour as a late complication of a frontal sinus reconstruction: case report and literature review. Rhinology 47: 470-475.

9. Verbon A, Husni RN, Gordon SM, Lavertu P, Keys TF (1996) Pott's puffy tumor due to Haemophilusinfluenzae: case report and review. Clin Infect Dis 23: 1305-1307.

10. Gleeson TD and C.F. Decker (2005) Sinusitis in Immunocompromised, Diabetic, and Human Immunodeficiency Virus-Infected Patients. Infectious disease and therapy series 35: 437.

11. Manfredi R, Calza L, Chiodo F (2002) Epidemiology and microbiology of cellulitis and bacterial soft tissue infection during HIV disease: a 10-year survey. J CutanPathol 29: 168-172.

12. Milgrim LM, Rubin JS, Rosenstreich DL, Small CB (1994) Sinusitis in human immunodeficiency virus infection: typical and atypical organisms. J Otolaryngol 23: 450-453.

13. Husta B and Reichner C (2012) Pott's Puffy Tumor: A Case with Intracranial and Pulmonary Manifestation. Chest 142: 167A-167A.

14. Sinto R and Wardani RS (2011) Subcutaneous Abscess on Frontal Region and Acute Exacerbated Chronic Multisinusitis on HIV-Infected Patient. Journal of the Indonesian Medical Association 59: 04

15. Tomas S (1986) Developmental anatomy and physiology of the nose and sinuses. Clinical Pediatric Otolaryngology 269-279.

16. Boodhoo H, Karen V (2006) Pott's puffy tumour -- the tip of an iceberg. S Afr Med J 96: 374-376. 